Article

\title{
Impact of COVID-19 Pandemic on Daily Lives, Agricultural Working Lives, and Mental Health of Farmers in Northern Thailand
}

\author{
Ratana Sapbamrer ${ }^{1,2, *(\mathbb{D})}$, Jiraporn Chittrakul ${ }^{1}$, Wachiranun Sirikul ${ }^{1} \mathbb{D}$, Amornphat Kitro ${ }^{1}$, Wilawan Chaiut ${ }^{1}$, \\ Pattarika Panya ${ }^{3}$, Patchareeya Amput ${ }^{4}$, Eakasit Chaipin ${ }^{5}$, Chatchada Sutalangka ${ }^{6}$, Suttinee Sidthilaw ${ }^{1}$, \\ Pornthip Promrak ${ }^{7}$, Pailinrak Kamolsan ${ }^{8}$ and Surat Hongsibsong ${ }^{2,9}$ (D)
}

Citation: Sapbamrer, R.; Chittrakul, J.; Sirikul, W.; Kitro, A.; Chaiut, W.; Panya, P.; Amput, P.; Chaipin, E.; Sutalangka, C.; Sidthilaw, S.; et al. Impact of COVID-19 Pandemic on Daily Lives, Agricultural Working Lives, and Mental Health of Farmers in Northern Thailand. Sustainability 2022, 14, 1189. https://doi.org/ $10.3390 /$ su14031189

Academic Editors: Roope Husgafvel and Haywantee Ramkissoon

Received: 8 November 2021

Accepted: 17 January 2022

Published: 21 January 2022

Publisher's Note: MDPI stays neutral with regard to jurisdictional claims in published maps and institutional affiliations.

Copyright: (c) 2022 by the authors. Licensee MDPI, Basel, Switzerland. This article is an open access article distributed under the terms and conditions of the Creative Commons Attribution (CC BY) license (https:// creativecommons.org/licenses/by/ $4.0 /)$.
1 Department of Community Medicine, Faculty of Medicine, Chiang Mai University, Chiang Mai 50200, Thailand; jerasooutch@gmail.com (J.C.); wachiranun.sir@gmail.com (W.S.); amornphat.kit@cmu.ac.th (A.K.); Wilawan.chai@mfu.ac.th (W.C.); Tik.sidthilaw@gmail.com (S.S.)

2 Environmental, Occupational Health Sciences and Non-Communicable Diseases Center of Excellence, Chiang Mai University, Chiang Mai 50200, Thailand; s_hongsibsong@hotmail.com

3 School of Nursing, Mae Fah Luang University, Chiang Rai 57100, Thailand; nn_cette@hotmail.com

4 Department of Physical Therapy, School of Allied Health Sciences, University of Phayao, Phayao 56000, Thailand; patchareeya.am@up.ac.th

5 Department of Public Health, Faculty of Science, Rajabhat Lampang University, Lampang 52100, Thailand eaksit.pin@gmail.com

6 Department of Physical Therapy, School of Integrative Medicine, Mae Fah Luang University, Chiang Rai 57100, Thailand; Chatchada.sut@mfu.ac.th

7 Department of Physical Therapy, Pua Crown Prince Hospital, Nan 55120, Thailand; Promruk.nuie@gmail.com

8 Department of Physical Therapy, Pang Mapha Hospital, Mae Hong Son 58150, Thailand; k.pailinrak@gmail.com

9 School of Health Sciences Research, Research Institute for Health Sciences, Chiang Mai University, Chiang Mai 50200, Thailand

* Correspondence: ratana.sapbamrer@cmu.ac.th; Tel.: +66-53935-472

\begin{abstract}
This study aims to determine the impact of COVID-19 on the daily lives, agricultural working lives, and mental health of farmers in northern Thailand. This cross-sectional study was carried out in September and October 2021 by interviews. From the stratified random sampling, 2046 farmers responded. There were five sections on the interview form, including demographics, daily life, agricultural working life, stress, and depression experienced during the COVID-19 pandemic. The results show that COVID-19 negatively affected the daily lives of the farmers, making it worse by $61.2 \%$. COVID-19 increased the cost of planting (57.4\%) and the cost of agrochemicals and fertilizers $(69.9 \%)$. It also decreased the prices of agricultural products $(73.5 \%)$ as well as agricultural extensions $(66.5 \%)$. The markets and logistics of agricultural products during the pandemic were more difficult than before it $(72.8 \%$ and $65.1 \%$, respectively). Half of the farmers $(50.3 \%)$ had moderate stress, and the highest scores were for the loss of household income (mean $\pm \mathrm{SD}=3.92 \pm 0.94$ ) and increased household expenses (mean $\pm \mathrm{SD}=3.92 \pm 0.98$ ). With regard to depression, $19.6 \%$ of farmers had depressive symptoms, and the multivariate analysis shows that the mental health of farmers was associated with the changes in their daily and agricultural working lives, as well as with financial problems. The remarkable findings indicate that the farmers who had high and extremely high stress levels had a higher prevalence of depression than the farmers who had no stress (adj.OR = 10.10 and 22.45 , respectively). Our results lead to the conclusion that the COVID-19 crisis had an impact on the daily lives, agricultural working lives, and mental health of farmers. The results of this study can be used to provide pertinent guidance, and they have implications for government and other relevant organizations in their COVID-19 efforts to improve agricultural systems and sustain the mental health of farmers.
\end{abstract}

Keywords: COVID-19; farmer; agriculture; mental health; depression; stress 


\section{Introduction}

The COVID-19 pandemic has triggered a serious human health crisis worldwide. As of November 3, 2021, COVID-19 had infected over 247 million people and is responsible for the deaths of 5 million people worldwide. In Thailand, COVID-19 has infected over 1.93 million people and is responsible for 19,394 million deaths [1,2]. Governments worldwide have implemented public health measures, including lockdowns, quarantine, and travel restrictions, to control the rapid spread of COVID-19. Although the measures have a high level of efficiency in controlling the spread of disease, they have also had an impact on several sectors, in particular, the public health, transportation, logistics, education, socioeconomic, and agricultural sectors [3-6]. With regard to the agricultural sector, the agriculture industry worldwide was not prepared to deal with a crisis such as COVID-19 [7]. A study by Pan et al. [8] suggests that COVID-19 has had an effect on crop production, the production supply, livestock production, the income and employment of farmers, economic crop development, sales models, product trade, and leisure. COVID-19 has also restricted agricultural extension services and the food supply to the markets [9].

The COVID-19 pandemic can have detrimental effects on mental health and wellbeing. The changes in daily and working lives may increase the risk of developing mental disorders, including stress, anxiety, depression, and suicidal thoughts [10-12]. Farmers are one of the vulnerable groups affected by the COVID-19 pandemic. The study by Cevher et al. [13] reveals that farmers had high levels of anxiety during the COVID-19 pandemic. They also found that factors such as age, place of residence, income, the type of farm, the size of the cultivated land, the use of trucks, animal husbandry, and access to support influenced the levels of anxiety. Understanding the factors that influence the mental health of farmers will inform the government and healthcare providers and help them to find problem-solving strategies. Psychiatrists play an important role in supporting people with mental health problems and the psychosocial consequences in this emergency crisis [14].

In Thailand, the COVID-19 pandemic has occurred in four waves. The fourth wave of COVID-19 had the highest numbers of confirmed cases and deaths in comparison to the other waves. After each wave of the pandemic, the government mandated public health control measures, including lockdowns, transportation control, working from home, physical distancing, and the closures of department stores, restaurants, markets, and food shops [15]. These measures have impacted various sectors, including the agricultural sectors. The agricultural sector is a major part of Thailand's economy. In 2020, agricultural production accounted for $8.65 \%$ of Thailand's gross domestic product (GDP) and contributed THB 1.36 trillion [16]. Agricultural households numbered approximately 7.55 million, and employed $35 \%$ of the total workforce $[17,18]$. However, the workforces in the agricultural sector have faced problems of poverty and debt, especially the workforces in the northern and northeastern regions of Thailand [18,19]. The COVID-19 crisis had a greater negative impact on farm households than general households. The income losses due to COVID-19 were $39 \%$ for farm households, in contrast to $19 \%$ for general households [19].

Most studies have determined the impact of COVID-19 on general populations; however, studies regarding the impact of COVID-19 on the agricultural working lives and mental health of farmers are scarce $[20,21]$. Therefore, this study aims to examine the impact of COVID-19 on the daily lives, agricultural working lives, and mental health of farmers in northern Thailand. We also determined the factors associated with stress levels and depression among farmers. The findings are useful in providing pertinent guidance and they have implications for the government and other relevant organizations in their COVID-19 efforts to improve the agricultural system and maintain the mental health of farmers.

\section{Materials and Methods}

\subsection{Study Design and Participants}

This cross-sectional study was conducted across eight provinces of northern Thailand: Chiang Mai, Chiang Rai, Lampang, Lamphun, Phrae, Nan, Payao and Mae Hong Son. 
The sample size was calculated using the Taro Yamane formula, and stratified random sampling was conducted (Figure 1) [22]. The participants were invited by invitation from health-promoting hospitals in September and October of 2021. The inclusion criteria for the participants were as follows: farmers aged 18 years and above; farmers living in one of the eight provinces in northern Thailand; and farmers able to communicate in the Thai language. Then participants were interviewed for approximately 10-15 min by trained interviewers.

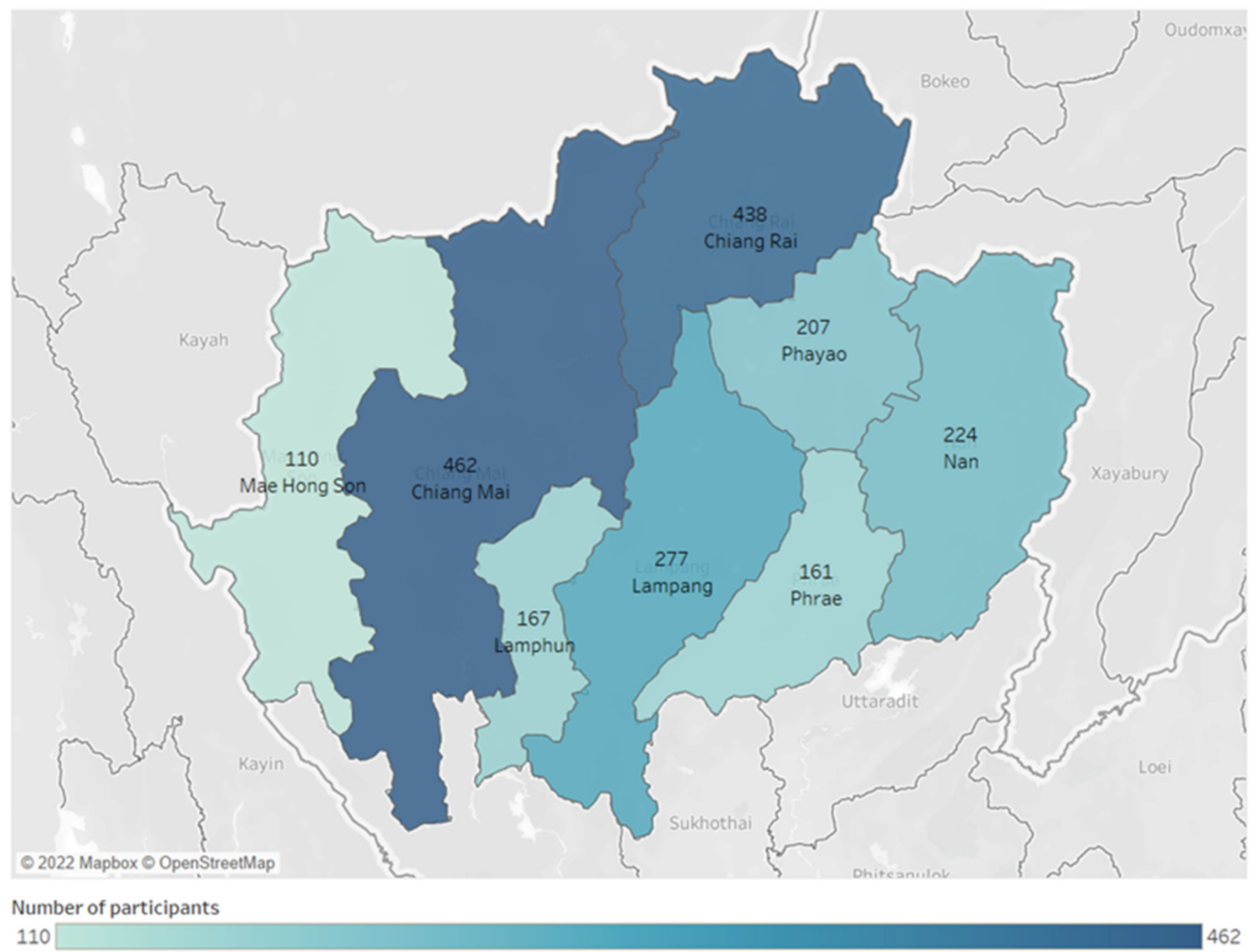

Figure 1. Stratified random sampling and numbers of samples in eight provinces of northern Thailand (Created by Tableau Desktop 2021.1, LLC, Seattle, WA, USA [22]).

\subsection{Interviews}

All of the interviewers were trained by the investigator team before interviewing the participants. Trained interviewers explained the objectives of the study, and asked question by question. The participants answered the questions according to their facts, opinions, and behaviors. There were five sections on the interview form, including demographics, daily life, agricultural working life, stress, and depression experienced during the COVID-19 pandemic. The questions regarding daily life included the behaviors of wearing a facemask, social distancing, and cleaning hands with alcohol. The questions regarding agricultural working life included: the type of agriculture; the rotation, duration, and method of plantation; the working hours; the labor, costs, and agrochemical and fertilizer use; agricultural production; logistics; and economic status. The pattern of questions regarding daily life and agricultural working life referred to the direction of the changes during the COVID-19 pandemic, compared with the time before the pandemic. The words in the answer choices included "changed", "unchanged", "decreased", "increased", "more difficult", and "easier". Mental health was defined using stress levels and depression. The stress levels were measured using a 5-point Likert rating scale: (1) no stress; (2) mild; (3) moderate; (4) high; and (5) extremely high. The participants were also asked 26 questions regarding the causes and levels of stress. Depression was measured using the Patient Health Questionnaire (PHQ-9) as a depression screening tool. There were nine questions, and the score options for each question were: not at all; several days; more than half the days; and nearly every 
day. The English language PHQ-9 was translated into Thai by Lotrakul et al. [23]. The continuous measure is a summary score ranging from 0 to 27 . The cut-off points for depressive symptoms were classified into four categories: less than 7 indicated no depressive symptoms; 7-12 indicated mild depressive symptoms; $13-18$ indicated moderate depressive symptoms; and equal to or higher than 19 indicated severe depressive symptoms. The Thai version of the PHQ-9 had acceptable internal consistency (Cronbach's alpha $=0.79$ ) and high specificity $(\mathrm{r}=0.98)$.

\subsection{Statistical Analysis}

The descriptive statistics, including the frequency (n), percentage (\%), mean, and standard deviation (SD), are presented. For the multivariate analysis, the demographic variables, and the variables that were significantly associated with stress levels and depression at $p<0.05$, were included in the model. Multiple linear regression with the stepwise method was used to determine the factors associated with the stress levels. Beta (B) and standard error (SE), and a 95\% confidence interval (95\%CI), were calculated and are presented. Binary logistic regression with the backward method was used to determine the factors associated with depression. Depression was categorized into two groups before the binary logistic regression analysis: depressive symptoms and no symptoms. Mild, moderate, and severe symptoms were classified as depression. The adjusted odds ratio (adj.OR) and a 95\%CI are presented.

\section{Results and Discussion}

\subsection{Demographic Characteristics of Farmers}

Table 1 presents the demographic characteristics of the farmers. The results found that nearly half of the farmers $(47.7 \%)$ had a household income of THB $1000-5000 /$ month, that $56.5 \%$ of them graduated from primary education, and that $82.3 \%$ of them were married. A total of $70 \%$ of the farmers had had at least one COVID-19 vaccination, and $54 \%$ of them had had two doses of the vaccine.

\subsection{Changes in Daily and Agricultural Working Lives Due to the COVID-19 Pandemic}

COVID-19 affected changes in the daily lives of the farmers in a worse direction $(61.2 \%)$. The majority of farmers $(87.1 \%)$ always wore facemasks when meeting other people, while $34.1 \%$ always wore masks when living with family members. Most of them (72.5\%) always maintained social distancing from others, and $25.5 \%$ always cleaned their hands with alcohol.

With regard to the changes in the agricultural working lives in a worse direction, the COVID-19 pandemic increased the costs of planting (57.4\%) and the costs of agrochemicals and fertilizers $(69.9 \%)$. It also decreased the prices of agricultural products $(73.5 \%)$, as well as the access to agricultural extensions $(66.5 \%)$. In addition, the markets and logistics of agricultural products during COVID-19 were more difficult to implement than in the past $(72.8 \%$ and $65.1 \%$, respectively). With regard to the economic aspects, the pandemic affected the losses of household income $(80 \%)$, while increasing expenses $(69.8 \%)$ and debt $(48.1 \%)$ at the same time (Table 2).

\subsection{Stress Levels and Depression Due to COVID-19 Pandemic}

Half of the farmers $(50.3 \%)$ had moderate stress, followed by those with high stress $(27.6 \%)$, mild stress $(17.7 \%)$, extremely high stress $(2.5 \%)$, and no stress $(1.9 \%)$. In terms of the causes of stress, the five issues that had the highest stress level scores were as follows: loss of household income (mean $\pm \mathrm{SD}=3.92 \pm 0.94$ ); increased household expenses (mean $\pm \mathrm{SD}=3.92 \pm 0.98$ ); increased COVID-19 cases (mean $\pm \mathrm{SD}=3.62 \pm 0.97$ ); increased death from COVID-19 cases (mean $\pm \mathrm{SD}=3.56 \pm 0.99$ ); wearing a facemask during the pandemic ( $3.55 \pm 1.12)$; and increased household debt (mean $\pm \mathrm{SD}=3.51 \pm 1.19$ ). In terms of depression, the majority of farmers $(80.4 \%)$ reported no symptoms, followed by those 
who reported mild symptoms (12.4\%), severe symptoms (3.7\%), and moderate symptoms (3.5\%) (Figure 2 and Table 3 ).

Table 1. Demographic characteristics of the farmers $(\mathrm{N}=2046)$.

\begin{tabular}{|c|c|c|}
\hline Parameter & & $\begin{array}{c}\text { n }(\%) \text { or } \\
\text { Mean } \pm \text { SD }\end{array}$ \\
\hline Age (years) & & $53 \pm 11$ \\
\hline Gender & $\begin{array}{c}\text { Male } \\
\text { Female }\end{array}$ & $\begin{array}{c}1077(52.6) \\
969(47.4)\end{array}$ \\
\hline Household income & $\begin{array}{l}<\text { THB } 1000 / \text { month } \\
\text { THB 1000-5000/month } \\
\text { THB 5001-10,000/month } \\
\text { >THB } 10,000 / \text { month }\end{array}$ & $\begin{array}{c}88(4.3) \\
975(47.7) \\
749(36.6) \\
234(11.4)\end{array}$ \\
\hline Education & $\begin{array}{c}\text { No study } \\
\text { Primary education } \\
\text { Secondary education } \\
\text { Bachelor's degree } \\
\text { Higher than bachelor's degree }\end{array}$ & $\begin{array}{c}82(4.0) \\
1155(56.5) \\
705(34.5) \\
97(4.7) \\
7(0.3)\end{array}$ \\
\hline Marital status & $\begin{array}{c}\text { Single } \\
\text { Married } \\
\text { Divorced/widowed }\end{array}$ & $\begin{array}{c}166(8.1) \\
1684(82.3) \\
196(9.6)\end{array}$ \\
\hline Comorbidity & $\begin{array}{l}\text { Yes } \\
\text { No }\end{array}$ & $\begin{array}{c}652(31.9) \\
1394(68.1)\end{array}$ \\
\hline COVID-19 vaccination & $\begin{array}{l}\text { Yes } \\
\text { No }\end{array}$ & $\begin{array}{c}1433(70) \\
613(30)\end{array}$ \\
\hline Number of COVID-19 vaccination doses & $\begin{array}{c}1 \\
2 \\
>2\end{array}$ & $\begin{array}{c}321(15.7) \\
1105(54.0) \\
7(0.3)\end{array}$ \\
\hline
\end{tabular}

n: frequency; SD: standard deviation.

Table 2. Changes in daily lives and agricultural working lives due to COVID-19 pandemic.

\begin{tabular}{|c|c|c|}
\hline Parameter & & n $(\%)$ \\
\hline Daily lifestyle & $\begin{array}{l}\text { Worse direction } \\
\text { Better direction } \\
\text { Unchanged }\end{array}$ & $\begin{array}{c}1252(61.2) \\
11(0.5) \\
783(38.3)\end{array}$ \\
\hline Wearing facemask when meeting other people & $\begin{array}{l}\text { Always } \\
\text { Sometimes } \\
\text { Never }\end{array}$ & $\begin{array}{c}1782(87.1) \\
232(11.3) \\
32(1.6)\end{array}$ \\
\hline Wearing facemask when living with family members & $\begin{array}{c}\text { Always } \\
\text { Sometimes } \\
\text { Never }\end{array}$ & $\begin{array}{l}697(34.1) \\
711(34.8) \\
638(31.2)\end{array}$ \\
\hline Keeping socially distanced from others & $\begin{array}{l}\text { Always } \\
\text { Sometimes } \\
\text { Never }\end{array}$ & $\begin{array}{c}1483(72.5) \\
540(26.4) \\
23(1.1)\end{array}$ \\
\hline Frequency of cleaning hands with alcohol & $\begin{array}{c}\text { Always } \\
\text { Sometimes } \\
\text { Never }\end{array}$ & $\begin{array}{c}522(25.5) \\
1405(68.7) \\
119(5.8)\end{array}$ \\
\hline Type of plant cultivation & $\begin{array}{c}\text { Changed } \\
\text { Unchanged }\end{array}$ & $\begin{array}{c}624(30.5) \\
1422(69.5)\end{array}$ \\
\hline Rotation of planting & $\begin{array}{c}\text { Decreased } \\
\text { Increased } \\
\text { Unchanged }\end{array}$ & $\begin{array}{c}504(24.6) \\
60(2.9) \\
1482(72.4)\end{array}$ \\
\hline Duration of planting & $\begin{array}{l}\text { Shorter period } \\
\text { Longer period } \\
\text { Unchanged }\end{array}$ & $\begin{array}{c}403(19.7) \\
88(4.3) \\
1555(76.0)\end{array}$ \\
\hline Method of planting & $\begin{array}{c}\text { Changed } \\
\text { Unchanged }\end{array}$ & $\begin{array}{c}261(12.8) \\
1785(87.2)\end{array}$ \\
\hline
\end{tabular}


Table 2. Cont.

\begin{tabular}{|c|c|c|}
\hline Parameter & & n $(\%)$ \\
\hline Number of days per week on the farm & $\begin{array}{l}\text { Decreased } \\
\text { Increased } \\
\text { Unchanged }\end{array}$ & $\begin{array}{c}743(36.3) \\
77(3.8) \\
1226(59.9)\end{array}$ \\
\hline Plant protection & $\begin{array}{l}\text { Decreased } \\
\text { Increased } \\
\text { Unchanged }\end{array}$ & $\begin{array}{c}484(23.7) \\
274(13.4) \\
1288(63.0)\end{array}$ \\
\hline Number of laborers & $\begin{array}{l}\text { Decreased } \\
\text { Increased } \\
\text { Unchanged }\end{array}$ & $\begin{array}{c}953(46.6) \\
45(2.2) \\
1048(51.2)\end{array}$ \\
\hline Costs of planting & $\begin{array}{l}\text { Increased } \\
\text { Decreased } \\
\text { Unchanged }\end{array}$ & $\begin{array}{c}1175(57.4) \\
188(9.2) \\
683(33.4)\end{array}$ \\
\hline Access to agrochemicals and fertilizers & $\begin{array}{l}\text { More difficult } \\
\text { Easier } \\
\text { Unchanged }\end{array}$ & $\begin{array}{c}708(34.6) \\
35(1.7) \\
1303(63.7)\end{array}$ \\
\hline Quantity of agrochemical and fertilizer use & $\begin{array}{l}\text { Increased } \\
\text { Decreased } \\
\text { Unchanged }\end{array}$ & $\begin{array}{c}559(27.3) \\
345(16.9) \\
1142(55.8)\end{array}$ \\
\hline Types of agrochemical and fertilizer use & $\begin{array}{l}\text { Changed } \\
\text { Unchanged }\end{array}$ & $\begin{array}{c}677(33.1) \\
1369(66.9)\end{array}$ \\
\hline Costs of agrochemicals and fertilizers & $\begin{array}{l}\text { Increased } \\
\text { Decreased } \\
\text { Unchanged }\end{array}$ & $\begin{array}{c}1430(69.9) \\
59(2.9) \\
557(27.2)\end{array}$ \\
\hline Crop yields & $\begin{array}{l}\text { Decreased } \\
\text { Increased } \\
\text { Unchanged }\end{array}$ & $\begin{array}{c}946(46.2) \\
94(4.6) \\
1006(49.2)\end{array}$ \\
\hline Prices of agricultural products & $\begin{array}{l}\text { Decreased } \\
\text { Increased } \\
\text { Unchanged }\end{array}$ & $\begin{array}{c}1504(73.5) \\
109(5.3) \\
433(21.2)\end{array}$ \\
\hline Quality of agricultural products & $\begin{array}{l}\text { Decreased } \\
\text { Increased } \\
\text { Unchanged }\end{array}$ & $\begin{array}{c}971(47.5) \\
123(6.0) \\
952(46.5)\end{array}$ \\
\hline Markets of agricultural products & $\begin{array}{l}\text { More difficult } \\
\text { Easier } \\
\text { Unchanged }\end{array}$ & $\begin{array}{c}1489(72.8) \\
48(2.3) \\
509(24.9)\end{array}$ \\
\hline Logistics of agricultural products & $\begin{array}{l}\text { More difficult } \\
\text { Easier } \\
\text { Unchanged }\end{array}$ & $\begin{array}{c}1332(65.1) \\
42(2.1) \\
672(32.8)\end{array}$ \\
\hline Access to agricultural extensions & $\begin{array}{l}\text { Decreased } \\
\text { Increased } \\
\text { Unchanged }\end{array}$ & $\begin{array}{c}1361(66.5) \\
35(1.7) \\
650(31.8)\end{array}$ \\
\hline Household income & $\begin{array}{l}\text { Decreased } \\
\text { Increased } \\
\text { Unchanged }\end{array}$ & $\begin{array}{c}1636(80.0) \\
72(3.5) \\
338(16.5)\end{array}$ \\
\hline Household expense & $\begin{array}{l}\text { Increased } \\
\text { Decreased } \\
\text { Unchanged }\end{array}$ & $\begin{array}{c}1428(69.8) \\
13(6.4) \\
487(23.8)\end{array}$ \\
\hline Household debt & $\begin{array}{l}\text { Increased } \\
\text { Decreased } \\
\text { Unchanged }\end{array}$ & $\begin{array}{c}985(48.1) \\
91(4.4) \\
970(47.4)\end{array}$ \\
\hline
\end{tabular}




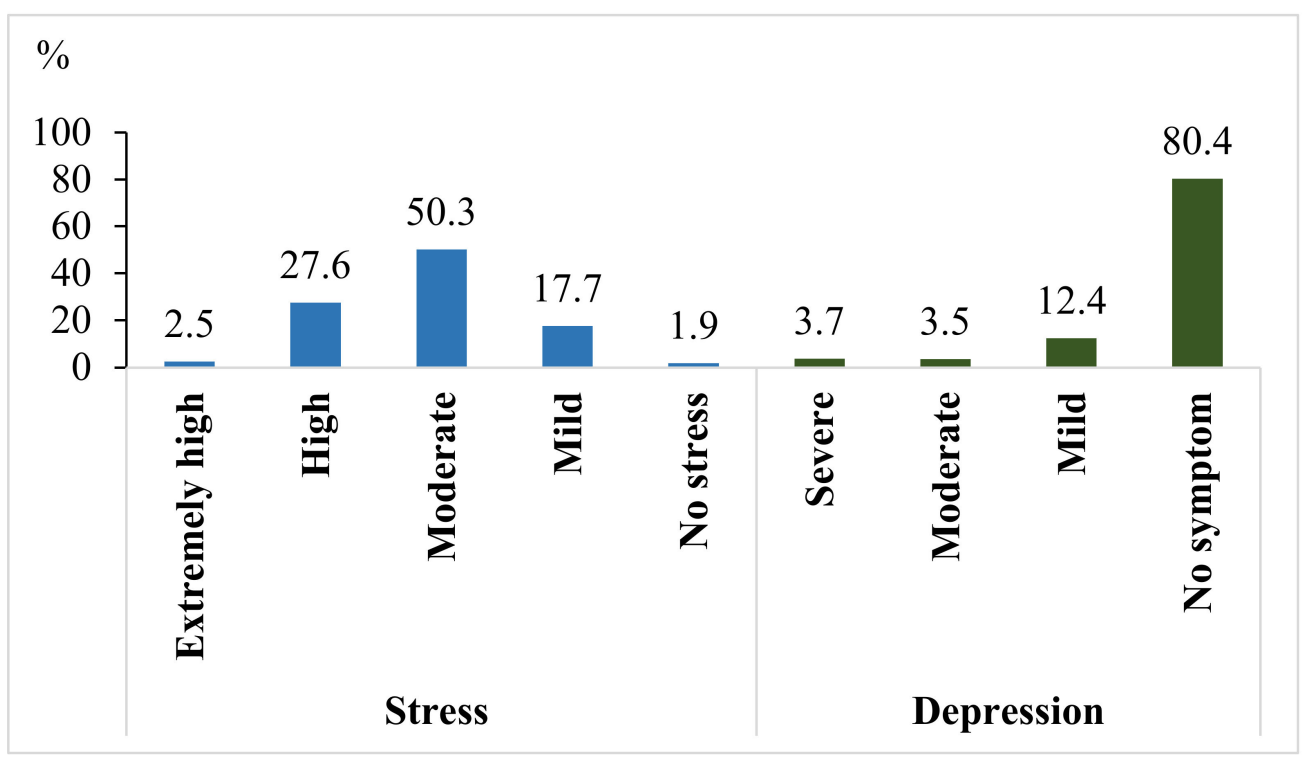

Figure 2. Stress and depression among farmers due to COVID-19 pandemic.

Table 3. Means \pm SD of stress levels.

\begin{tabular}{cc}
\hline Causes & Mean \pm SD \\
\hline Household income & $3.92 \pm 0.94$ \\
Household expenses & $3.92 \pm 0.98$ \\
COVID-19 cases & $3.62 \pm 0.97$ \\
Death from COVID-19 cases & $3.56 \pm 0.99$ \\
Wearing a facemask & $3.55 \pm 1.12$ \\
Household debt & $3.51 \pm 1.19$ \\
Maintaining social distancing & $3.49 \pm 1.11$ \\
Prices of agricultural products & $3.47 \pm 1.15$ \\
Markets of agricultural products & $3.47 \pm 1.20$ \\
Costs of planting & $3.42 \pm 1.09$ \\
Cleaning hands with alcohol & $3.41 \pm 1.12$ \\
Logistics of agricultural products & $3.30 \pm 1.24$ \\
Costs of agrochemicals and fertilizers & $3.36 \pm 1.21$ \\
Type of plant cultivation & $3.25 \pm 1.06$ \\
Crop yields & $3.16 \pm 1.18$ \\
Quality of agricultural products & $3.14 \pm 1.15$ \\
Access to agrochemicals and fertilizers & $3.05 \pm 1.16$ \\
Quantity of agrochemical and fertilizer use & $3.01 \pm 1.15$ \\
Type of agrochemical and fertilizer use & $2.98 \pm 1.16$ \\
Labor & $2.98 \pm 1.12$ \\
Rotation of planting & $2.89 \pm 1.08$ \\
Number of days on the farm & $2.87 \pm 1.06$ \\
Duration of planting & $2.86 \pm 1.06$ \\
Planting protection & $2.85 \pm 1.09$ \\
Method of planting & $2.81 \pm 1.08$ \\
Access to agricultural extensions & $2.67 \pm 1.24$ \\
\hline SD:standard deviation &
\end{tabular}

SD: standard deviation.

\subsection{Factors Associated with Stress Levels among Farmers Due to COVID-19}

A multiple linear regression analysis found that stress levels were positively associated with having a comorbidity $(\mathrm{B} \pm \mathrm{SE}=0.094 \pm 0.033)$, changes in daily life ( $\pm \mathrm{SE}=0.131 \pm 0.019)$, and cleaning hands with alcohol $(\mathrm{B} \pm \mathrm{SE}=0.116 \pm 0.020)$. It was also positively associated with changes in the type and method of planting $(B \pm S E=0.226 \pm 0.041$ and $0.274 \pm 0.049)$, the decreased rotation of planting and crop yields $(\mathrm{B} \pm \mathrm{SE}=0.074 \pm 0.027$ and $0.063 \pm 0.018$ ), difficulty in logistics $(B \pm S E=0.099 \pm 0.020)$, decreased access to agricultural extensions 
$(\mathrm{B} \pm \mathrm{SE}=0.100 \pm 0.019)$, and increased household debt $(\mathrm{B} \pm \mathrm{SE}=0.090 \pm 0.017)$. Stress levels were also negatively associated with wearing a facemask when meeting other people and while living with family members $(\mathrm{B} \pm \mathrm{SE}=-0.154 \pm 0.041$, and $-0.071 \pm 0.021$, respectively), shorter periods of planting $(B \pm S E=-0.149 \pm 0.029)$, and the increased costs of planting $(\mathrm{B} \pm \mathrm{SE}=-0.042 \pm 0.018)$ (Table 4$)$.

Table 4. Multiple linear regression for analyzing factors associated with stress levels among farmers due to COVID-19 pandemic.

\begin{tabular}{cllcc}
\hline Factors & B & SE & 95\%CI & $p$ Value \\
\hline Having comorbidity & 0.094 & 0.033 & $0.029,0.159$ & $0.005^{* *}$ \\
Changes in daily life & 0.131 & 0.019 & $0.093,0.170$ & $<0.001^{* *}$ \\
Wearing facemask when meeting other people & -0.154 & 0.041 & $-0.235,-0.073$ & $<0.001^{* *}$ \\
Wearing facemask when living with family & -0.071 & 0.021 & $-0.112,-0.030$ & $0.001^{* *}$ \\
members & 0.116 & 0.020 & $0.076,0.155$ & $<0.001^{* *}$ \\
Frequency of cleaning hands with alcohol & 0.226 & 0.041 & $0.145,0.307$ & $<0.001^{* *}$ \\
Change in type of plant cultivation & 0.074 & 0.027 & $0.020,0.127$ & $0.007^{* *}$ \\
Decreased rotation of planting & -0.149 & 0.029 & $-0.207,-0.091$ & $<0.001^{* *}$ \\
Shorter period of planting & 0.274 & 0.049 & $0.178,0.369$ & $<0.001^{* *}$ \\
Change in method of planting & -0.042 & 0.018 & $-0.076,-0.007$ & $0.018^{*}$ \\
Increased costs of planting & 0.063 & 0.018 & $0.028,0.098$ & $<0.001^{* *}$ \\
Decreased crop yields & 0.099 & 0.020 & $0.059,0.138$ & $<0.001^{* *}$ \\
Difficulty in logistics & 0.100 & 0.019 & $0.064,0.137$ & $<0.001^{* *}$ \\
Increased household debt & 0.090 & 0.017 & $0.056,0.123$ & $<0.001^{* *}$ \\
\hline
\end{tabular}

B: beta; SE: standard error; $95 \%$ CI: $95 \%$ confidence interval; ${ }^{*} p<0.05 ;{ }^{* *} p<0.01$.

\subsection{Factors Associated with Depression among Farmers Due to COVID-19}

The binary logistic regression analysis found that the demographic factors associated with depression were: gender (adj.OR $=1.34,95 \% \mathrm{CI}=1.02-1.77$ for males); marital status (adj.OR $=2.20,95 \% \mathrm{CI}=1.24-3.89$ for divorced $/$ widowed); comorbidity (adj. $\mathrm{OR}=1.54$, $95 \% \mathrm{CI}=1.15-2.07$ ); and COVID-19 vaccination (adj.OR $=0.51,95 \% \mathrm{CI}=0.37-0.71$ ). Daily life factors included: wearing a facemask when meeting other people (adj.OR $=4.13$, $95 \% \mathrm{CI}=1.61-10.63$ for sometimes, and adj.OR $=2.98,95 \% \mathrm{CI}=1.95-4.54$ for never); wear ing a facemask when living with family members (adj.OR $=0.229,95 \% \mathrm{CI}=0.15-0.35$ for sometimes, and adj.OR $=0.52,95 \% \mathrm{CI}=0.37-0.73$ for never); and cleaning hands with alcohol (adj.OR $=2.38,95 \% \mathrm{CI}=1.07-5.28$ for always). The agricultural factors included the type of plant cultivation (adj.OR $=1.64,95 \% \mathrm{CI}=1.22-2.21$ ), plant protection (adj. $\mathrm{OR}=2.05,95 \% \mathrm{CI}=1.47-2.85$ ), and access to agrochemicals and fertilizers (adj. $\mathrm{OR}=1.63,95 \% \mathrm{CI}=1.19-2.21$ for easier access, and adj. $\mathrm{OR}=3.71,95 \% \mathrm{CI}=1.48-9.31$ for more difficult). The economic factors included the loss of household income (adj.OR $=1.72$, $95 \% \mathrm{CI}=1.06-2.79$ ) and changes in household debt (adj. $\mathrm{OR}=2.98,95 \% \mathrm{CI}=2.13-4.17$ for decreased debt, and adj.OR $=6.15,95 \% \mathrm{CI}=2.99-12.66$ for increased debt).

In terms of the stress levels associated with depression, the farmers who reported high and extremely high stress levels had a higher prevalence of depression than the farmers who had no stress (adj.OR $=10.10,95 \% \mathrm{CI}=1.26-80.79$ for high stress levels, and adj. $\mathrm{OR}=22.45,95 \% \mathrm{CI}=2.55-197.65$ for extremely high stress levels) (Table 5). 
Table 5. Binay logistic regression for analyzing factors associated with depression among farmers due to COVID-19 pandemic.

\begin{tabular}{|c|c|c|c|c|c|}
\hline Factors & & n (\%) & Adj.OR & $95 \% \mathrm{CI}$ & $p$ Value \\
\hline \multirow{5}{*}{ Marital status } & Female (ref.) & $165(17.0)$ & & & \\
\hline & Male & $236(21.9)$ & 1.34 & $1.02,1.77$ & $0.039 *$ \\
\hline & Single (ref.) & $40(24.1)$ & & & \\
\hline & Married & $281(16.7)$ & 0.74 & $0.47,1.17$ & 0.199 \\
\hline & $\begin{array}{l}\text { Divorced/ } \\
\text { widowed }\end{array}$ & $80(40.8)$ & 2.20 & $1.24,3.89$ & $0.007^{* *}$ \\
\hline \multirow[t]{2}{*}{ Comorbidity } & No (ref.) & $252(18.1)$ & & & \\
\hline & Yes & $149(22.9)$ & 1.54 & $1.15,2.07$ & $0.004^{* *}$ \\
\hline \multirow[t]{2}{*}{ COVID-19 vaccination } & Yes (ref.) & 33. (23.0) & & & \\
\hline & No & $71(11.6)$ & 0.51 & $0.37,0.71$ & $<0.001^{* *}$ \\
\hline \multirow{3}{*}{$\begin{array}{l}\text { Wearing facemask when } \\
\text { meeting other people }\end{array}$} & Always (ref.) & $302(16.9)$ & & & \\
\hline & Sometimes & $84(36.2)$ & 4.13 & $1.61,10.63$ & 0.030 * \\
\hline & Never & $15(46.9)$ & 2.98 & $1.95,4.54$ & $<0.001^{* *}$ \\
\hline \multirow{3}{*}{$\begin{array}{l}\text { Wearing facemask when } \\
\text { living with family } \\
\text { members }\end{array}$} & Always (ref.) & $189(27.1)$ & & & \\
\hline & Sometimes & $157(22.1)$ & 0.23 & $0.15,0.35$ & $<0.001^{* *}$ \\
\hline & Never & $55(8.6)$ & 0.52 & $0.37,0.73$ & $<0.001^{* *}$ \\
\hline \multirow{3}{*}{$\begin{array}{l}\text { Cleaning hands with } \\
\text { alcohol }\end{array}$} & Never (ref.) & $14(11.8)$ & & & \\
\hline & Sometimes & $273(19.4)$ & 1.84 & $0.87,3.88$ & 0.110 \\
\hline & Always & $114(21.8)$ & 2.38 & $1.07,5.28$ & $0.033 *$ \\
\hline \multirow{2}{*}{ Type of plant cultivation } & Unchanged (ref.) & $184(12.9)$ & & & \\
\hline & Changed & $217(34.8)$ & 1.64 & $1.22,2.21$ & $0.001^{* *}$ \\
\hline \multirow[t]{3}{*}{ Plant protection } & Unchanged (ref.) & $162(12.6)$ & & & \\
\hline & Decreased & $36(13.1)$ & 0.74 & $0.46,1.19$ & 0.219 \\
\hline & Increased & $203(41.9)$ & 2.05 & $1.47,2.85$ & $<0.001^{* *}$ \\
\hline \multirow{3}{*}{$\begin{array}{l}\text { Access to agrochemicals } \\
\text { and fertilizers }\end{array}$} & Unchanged (ref.) & $189(14.5)$ & & & \\
\hline & Easier & $11(31.4)$ & 1.63 & $1.19,2.21$ & $0.002 * *$ \\
\hline & More difficult & $201(28.4)$ & 3.71 & $1.48,9.31$ & $0.005^{* *}$ \\
\hline \multirow[t]{3}{*}{ Household income } & Unchanged (ref.) & $39(11.5)$ & & & \\
\hline & Increased & $8(11.1)$ & 0.71 & $0.25,2.07$ & 0.129 \\
\hline & Decreased & $354(21.6)$ & 1.72 & $1.06,2.79$ & 0.028 * \\
\hline \multirow[t]{3}{*}{ Household debt } & Unchanged (ref.) & $83(8.6)$ & & & \\
\hline & Decreased & $29(31.9)$ & 2.98 & $2.13,4.17$ & $<0.001^{* *}$ \\
\hline & Increased & $289(29.3)$ & 6.15 & $2.99,12.66$ & $<0.001^{* *}$ \\
\hline \multirow[t]{5}{*}{ Stress level } & No (ref.) & $1(2.6)$ & & & \\
\hline & Mild & $19(5.2)$ & 1.90 & $0.23,16.00$ & 0.554 \\
\hline & Moderate & $184(17.9)$ & 4.57 & $0.57,36.96$ & 0.151 \\
\hline & High & $168(29.7)$ & 10.10 & $1.26,80.79$ & $0.029 *$ \\
\hline & Extremely high & $29(56.9)$ & 22.45 & $2.55,197.65$ & $0.005^{* *}$ \\
\hline
\end{tabular}

n: frequency; adj.OR: adjusted odds ratio; 95\%CI: 95\% confidence interval; ${ }^{*} p<0.05 ;{ }^{* *} p<0.01$.

\section{Discussion}

The COVID-19 pandemic changed the daily lives of farmers in a worse direction. In our study, the farmers reported suffering from the government measures put in place to control the rapid spread of COVID-19, such as wearing facemasks when meeting other people and maintaining social distancing from others. The study by Wang et al. [24] found an association between mental health and facemask use. Wearing a facemask might cause an internal conflict of stress, leading to confusion and mental distress [25].

In terms of the changes in agricultural working lives, our study reveals that COVID-19 had an impact on the costs of planting, the costs of agrochemicals and fertilizers, the prices of agricultural products, and the markets and logistics of agricultural products. These results agree with previous studies that suggest that COVID-19 affected crop production, 
the production supply, livestock production, the income and employment of farmers, economic crop development, sales models, product trade, and agricultural extension services $[8,9]$. All these changes could be the result of the farmers' financial problems. Thai farmers have faced poverty for many years and, therefore, the COVID-19 crisis has the potential to push the Thai people into extreme poverty [20]. In terms of the markets and logistics of agricultural products, transportation and border restrictions might affect these, resulting in changes in consumer demand and the delivery of agricultural products to markets [26].

Psychological stress is the body's response to pressured situations, and it contributes to a variety of physical and mental health issues [27]. Our results found that half of the farmers $(50.3 \%)$ had moderate stress due to COVID-19. Importantly, the results also found that the highest stress level scores were found in relation to the loss of household income and increased household expenses. It is likely that farmers were more concerned about economic losses than changes in agricultural working life. Importantly, our results show that the farmers who had high and extremely high stress levels had a higher prevalence of depression than the farmers who had no stress $(\mathrm{OR}=10.10$ and 22.45). Depression is the most common mental disorder worldwide. It is a mood disorder that can cause serious problems in daily life, and that can potentially lead to suicide. Depression is caused by a complex interaction of biological, social, and psychological factors. Psychological stress is an important factor affecting depression [28,29], and it can increase the risk of depression. In this study, the PHQ-9 was used as a depression screening tool. The PHQ-9 is a reliable and valid instrument used to screen for depression in primary care and to aid diagnosis. The detection of depression in its early stages may improve mental health before it progresses to more extensive problems [30]. Therefore, the government and healthcare providers should establish medical support systems to improve the mental health of farmers, coupled with agricultural and economic support.

Biological factors, including gender, marital status, and comorbidity, were determinants of the mental health of farmers. Our results indicate that the farmers who were male, divorced/widowed, or who had comorbidities had a higher prevalence of mental health problems. The study by Ragasa et al. [31] suggests that men were more pessimistic about income loss than women. Asian men are usually the heads of the family and the main wage earners, so, in this study, they took a more serious view in terms of the effects of income. Married people are perceived as more likely to have greater social support, so marriage enhances psychological wellbeing [32]. People living with chronic physical diseases might have chronic pain and emotional stress, leading to the development of mental disorders [33].

The changes in the aspects of agricultural working life during COVID-19 were also an important factor affecting the mental health of farmers. In our study, the agricultural factors affecting the mental health of farmers included the type of farming, the methods and costs of planting, the rotation and periods of planting, plant protection, logistics, agricultural extension services, crop yields, and access to agrochemicals and fertilizers. Lockdown and other measures potentially threaten agricultural production systems and crop yields. The measures limited access to farms, and the maintenance of social distancing resulted in a shortage of labor and decreased crop yields. The measures implemented during the harvesting periods of some crops resulted in the spoilage of ready-to-harvest products, consequently decreasing crop yields, and leading to a shortage of food supplies in the markets. Logistical problems in terms of the provision of agrochemicals, fertilizers, and seeds were another reason for the decreased crop yields. Decreased crop yields were also associated with reductions in purchasing power and food demand, which were due to the closure of restaurants, food shops, and hotels $[26,34,35]$. The reduction in consumer purchasing power is another reason behind the decrease in the income of farmers over the long term. When the income of farmers is reduced, they might attempt to reduce expenses associated with the type and method of planting, the rotation and duration of planting, and crop protection. In this case, this resulted in a reduction in the quantity and quality of 
the crops [7]. The study by Timilsina et al. [36] suggests that the government should take action to provide quality seeds, fertilizers, technology, and financial support to farmers to help with the improvement of the agricultural sector during the pandemic. Agricultural extensions also play a vital role in the translation of research into practices. Guidance from agricultural extensions could help farmers in their adaptation, enabling them to survive during the current COVID-19 crisis [37]. Direct access to agricultural extensions during COVID-19 was more difficult because of the transportation restrictions and social distancing measures [9]. Finding suitable communication approaches towards farmers should be considered. An improvement in the functional performance of the infrastructure in the agricultural sectors by government and agricultural extensions could enhance resilience [26]. Therefore, support from the government and agricultural extensions is key for enhancing food security, as well as for the maintenance of a sustainable agricultural system.

Economic factors were recorded as being crucial for the mental health of farmers. In our study, farmers who faced financial problems had a higher prevalence of mental health problems than the farmers who did not face these problems. Our results agree with the study by Paul et al. [38], which suggests that farmers were feeling higher levels of stress $(\mathrm{OR}=3.029,95 \% \mathrm{CI}=1.079-8.502)$ than unemployed people. Most Thai farmers are classified as being in the lower income bracket, and the study shows that they earn a living by daily income. Furthermore, most farmers were classified as vulnerable people, who were unable to maintain livelihoods, and who had difficulty accessing financial support, technology, tools, and knowledge [26]. The measures during COVID-19 may have threatened the work on the farms, markets, and logistics. This threatened their livelihoods and economic status, resulting in psychological suffering [38]. During the COVID-19 crisis, the Thai government launched relief measures to alleviate the impact. The government paid compensation to informal workers, at a rate of THB 5000 per person for three months, transferring the money to a bank account registered with PromptPay by an ID Card [39]. Most of the farmers were classed as informal workers. However, this program was designed for workers who had mobile phone and Internet access. In actuality, most Thai farmers are poor and illiterate, so this program made it more difficult to get this compensation support. Therefore, looking to the future, the government should design a program that is more suited and more accessible to farmers. Informal workers in Thailand, which include farmers, also face health and safety problems at work because labor legislation has not protected all of the informal sectors. Under the labor legislation, informal workers are classified as "self-employed", rather than as "employees". Therefore, the farmers were not covered by the legislation in matters of health and safety $[40,41]$. Most farmers usually receive health services from primary healthcare units near their villages. However, this is only provisional treatment, as the capacities of health facilities are not sufficient. There is also a shortage of medical specialists in the healthcare units [42], especially occupational physicians and psychiatrists. In addition, there are several barriers to the primary healthcare units for informal workers, including a lack of knowledge about occupational health hazards and occupational diseases, no relationship with occupational physicians, no referral pathways, no time to visit a workplace, and long waiting times for specialists [43]. Therefore, the government should safeguard the health of informal workers and increase the capacities of primary healthcare facilities in terms of the staffing workforce and health professional skills.

To improve the agricultural system and the mental health of farmers during the COVID-19 pandemic, interdisciplinary collaboration should be pursued. The government and relevant agricultural organizations should improve the functioning of the infrastructure in agricultural sectors to maintain the agricultural system [26]. The government needs to establish medium- to long-term plans to address the mental health consequences during the pandemic [44]. Healthcare providers should establish a medical support system to improve the mental health of farmers. A mental health consultation system should be developed to advise primary healthcare providers and other health professionals [10,12]. Stewart and Appelbaum [45] point out that psychiatrists need to continue to diagnose, treat, and 
manage their patients through the possible approaches, including through telemedicine and other virtual forms of care. In addition, providing online mental health services could increase the opportunities to reach people with mental health problems [43]. Psychiatrists should be involved in the decision-making committees and the triage in their hospitals in order to protect the human rights of people with mental disorders. Psychiatrists should also lobby governments, policymakers and service planners to increase the availability of mental health services and psychological interventions [43,44]. Therefore, psychiatrists play a key role in supporting the healthcare system and promoting psychological interventions.

The strength of this study is the extensive sample used for the data collection during the period of the fourth wave of COVID-19 in Thailand. This wave had the highest numbers of confirmed cases and death cases, compared with the other waves. The results from this study and other similar work is useful for government and other relevant organizations when they are managing their COVID-19 efforts and policymaking. However, there are some limitations. First, the cross-sectional design of this study might not clearly explain some causal relationships. A longitudinal study in further research could yield useful insights for government, policymakers, and healthcare providers. Second, the stress level assessment instrument has not been validated, so the results may be difficult to compare with other studies. Third, some sociodemographic factors, which have an impact on mental health, were not collected, including the number of people in the households and the levels of satisfaction with their own lives. Further research needs to be concerned with these factors. Last, the study was only conducted on farmers in northern Thailand; therefore, the findings may not be transferable to other areas. Further research needs to be carried out on farmers in other regions of Thailand.

\section{Conclusions}

Our study led to the conclusion that the COVID-19 crisis had an impact on the daily lives, agricultural working lives, and mental health of farmers. Agricultural and household economic problems are factors that have an important impact on the mental health of farmers. These results should be taken into consideration when solving problems through interdisciplinary collaboration. The agricultural extensions provided by the government play a vital role in providing training programs. The main issues that need addressing in training programs during the COVID-19 crisis include the selection of the type and method of planting, the methods of enhancing agricultural productivity, and plant protection practices. Support from the government in terms of agricultural markets, prices, and logistics is also relevant to solving the problem. The government needs to establish mediumto long-term plans in order to address the mental health consequences during the pandemic. An amendment of the labor legislation is needed to protect the health of all informal workers. Enhancing the capacities of primary healthcare facilities, in terms of the staffing workforce and health professional skills, is also needed. Furthermore, government and healthcare providers should establish medical support systems to improve the mental health of farmers. A mental health consultation system should be developed to advise primary healthcare providers and other health professionals. Providing online mental health services could increase the opportunities to reach people with mental health problems. All these supports could reduce the household economic problems of farmers, and could, consequently, decrease the mental disorders in this large demographic. Therefore, government and relevant organizations have key roles to play in solving these problems. The results of this study can provide useful guidance and they have implications for government and other relevant organizations in their COVID-19 efforts to sustainably improve agricultural systems and the mental health of farmers. To enhance agricultural systems and the mental health of farmers in a sustainable way, more research, in a longitudinal investigation, is needed. The longitudinal investigation could provide information about the trends of the changes in the long-term effects of the COVID-19 pandemic. 


\begin{abstract}
Author Contributions: Conceptualization, R.S. and J.C.; data curation, R.S.; formal analysis, R.S.; funding acquisition, R.S.; investigation, R.S., J.C., W.C., P.P. (Pattarika Panya), P.A., E.C., C.S., S.S., P.P. (Pornthip Promrak), P.K. and S.H.; methodology, R.S., J.C., W.S. and A.K.; project administration, R.S.; resources, R.S., J.C., W.S., A.K., W.C., P.P. (Pattarika Panya), P.A., E.C., C.S., S.S., P.P. (Pornthip Promrak), P.K. and S.H.; software, R.S.; supervision, R.S.; validation, R.S., J.C., W.S., A.K., W.C., P.P. (Pattarika Panya), P.A., E.C., C.S., S.S., P.P. (Pornthip Promrak), P.K. and S.H.; visualization, R.S. and J.C.; writing—original draft, R.S.; writing—review and editing, R.S. All authors have read and agreed to the published version of the manuscript.
\end{abstract}

Funding: This research was funded by the Faculty of Medicine Research Fund, Chiang Mai University, grant number [009/2565], and the Environmental, Occupational Health Sciences and Non Communicable Diseases Center of Excellence, the Chiang Mai University Research Fund.

Institutional Review Board Statement: The study was conducted in accordance with the Declaration of Helsinki and approved by the Institutional Review Board of The Human Ethical Committee at the Faculty of Medicine, Chiang Mai University (protocol code 412/2564 and date of approval 15 September 2021).

Informed Consent Statement: Informed consent was obtained from all subjects involved in the study.

Data Availability Statement: Not applicable.

Acknowledgments: We wish to acknowledge the Research Administration Section, Faculty of Medicine, Chiang Mai University, for their assistance with the editing of the English language. We thank all participants to participate in the study.

Conflicts of Interest: The authors declare no potential conflict of interest with respect to the research strategy, authorship, and/or publication of this article.

\title{
References
}

1. World Health Organization. WHO Coronavirus (COVID-19) Dashboard. Available online: https://covid19.who.int (accessed on 3 November 2021).

2. Department of Disease Control. Thailand. Corona Virus Disease (COVID-19): Thailand Situation. Available online: https: / /ddc. moph.go.th/viralpneumonia/eng/index.php (accessed on 3 November 2021).

3. Siche, R. What is the impact of COVID-19 disease on agriculture? Sci. Agropecu. 2020, 11, 3-6. [CrossRef]

4. Meuwissen, M.; Feindt, P.; Slijper, T.; Spiegel, A.; Finger, R.; de Mey, Y.; Paas, W.; Termeer, K.; Poortvliet, P.; Peneva, M.; et al. Impact of COVID-19 on farming systems in Europe through the lens of resilience thinking. Agric. Syst. 2021, 191, 103152. [CrossRef]

5. Liu, S.; Ermolieva, T.; Cao, G.; Chen, G.; Zheng, X. Analyzing the Effectiveness of COVID-19 Lockdown Policies Using the Time-Dependent Reproduction Number and the Regression Discontinuity Framework: Comparison between Countries. Eng. Proc. 2021, 5, 8. [CrossRef]

6. Nicola, M.; Alsafi, Z.; Sohrabi, C.; Kerwan, A.; Al-Jabir, A.; Iosifidis, C.; Agha, M.; Agha, R. The socio-economic implications of the coronavirus pandemic (COVID-19): A review. Int. J. Surg. 2020, 78, 185-193. [CrossRef] [PubMed]

7. Lioutas, E.D.; Charatsari, C. Enhancing the ability of agriculture to cope with major crises or disasters: What the experience of COVID-19 teaches us. Agric. Syst. 2021, 187, 103023. [CrossRef]

8. Pan, D.; Yang, J.; Zhou, G.; Kong, F. The influence of COVID-19 on agricultural economy and emergency mitigation measures in China: A text mining analysis. PLoS ONE 2020, 15, e241167. [CrossRef]

9. Bright, M.P.; Kudzai, N.T.; Ngavaite, C. The impact of COVID-19 on agricultural extension and food supply in Zimbabwe. Cogent Food Agric. 2021, 7, 1918428. [CrossRef]

10. Fiorillo, A.; Gorwood, P. The consequences of the COVID-19 pandemic on mental health and implications for clinical practice. Eur. Psychiatry 2020, 63, e32. [CrossRef]

11. Yang, L.; Zhao, Y.; Wang, Y.; Liu, L.; Zhang, X.; Li, B.; Cui, R. The Effects of Psychological Stress on Depression. Curr. Neuropharmacol. 2015, 13, 494-504. [CrossRef]

12. Unützer, J.; Kimmel, R.J.; Snowden, M. Psychiatry in the age of COVID-19. World Psychiatry 2020, 19, 130-131. [CrossRef]

13. Cevher, C.; Altunkaynak, B.; Gürü, M. Impacts of COVID-19 on Agricultural Production Branches: An Investigation of Anxiety Disorders among Farmers. Sustainability 2021, 13, 5186. [CrossRef]

14. Marazziti, D.; Stahl, S.M. The relevance of COVID-19 pandemic to psychiatry. World Psychiatry 2020, 19, 261. [CrossRef]

15. Tantrakarnapa, K.; Bhopdhornangkul, B.; Nakhaapakorn, K. Influencing factors of COVID-19 spreading: A case study of Thailand. J. Public Health 2020, 1-7. [CrossRef]

16. The World Bank. Agriculture, Forestry, and Fishing, Value Added (\% of GDP)—Thailand. Available online: https://data.worldbank. org/indicator/NV.AGR.TOTL.ZS?year_high_desc=true\&locations=TH (accessed on 12 August 2021).

17. Manakitsomboon, H. Agriculture in Thailand-Statistics \& Facts. Statista. 2021. Available online: https://www.statista.com/ topics/5730/agriculture-in-thailand/\#dossierKeyfigures (accessed on 12 August 2021). 
18. Food and Agricultural Organization. Thailand. Socio-Economic Context and Role of Agriculture. Country Fact Sheet on Food and Agriculture Policy Trends. Available online: http://www.fao.org/3/i8683en/I8683EN.pdf (accessed on 5 September 2021).

19. Udomkerdmongkol, M. Thai Agricultural Sector: From Problems to Solutions. United Nations Thailand. Available online: https:/ / thailand.un.org/th/node/103307 (accessed on 10 October 2021).

20. Pramukti, I.; Strong, C.; Sitthimongkol, Y.; Setiawan, A.; Pandin, M.G.R.; Yen, C.-F.; Lin, C.-Y.; Griffiths, M.D.; Ko, N.-Y. Anxiety and Suicidal Thoughts During the COVID-19 Pandemic: Cross-Country Comparative Study Among Indonesian, Taiwanese, and Thai University Students. J. Med. Int. Res. 2020, 22, e24487. [CrossRef]

21. Apisarnthanarak, A.; Apisarnthanarak, P.; Siripraparat, C.; Saengaram, P.; Leeprechanon, N.; Weber, D.J. Impact of anxiety and fear for COVID-19 toward infection control practices among Thai healthcare workers. Infect. Control Hosp. Epidemiol. 2020, 41, 1093-1094. [CrossRef] [PubMed]

22. Tableau Desktop 2021.1, LLC, Seattle, WA, USA. Available online: https://www.tableau.com/support/releases/desktop/2021.1 (accessed on 18 January 2022).

23. Lotrakul, M.; Sumrithe, S.; Saipanish, R. Reliability and validity of the Thai version of the PHQ-9. BMC Psychiatry 2008, 8, 1-7. [CrossRef] [PubMed]

24. Wang, C.; Chudzicka-Czupała, A.; Grabowski, D.; Pan, R.; Adamus, K.; Wan, X.; Hetnał, M.; Tan, Y.; Olszewska-Guizzo, A.; $\mathrm{Xu}$, L.; et al. The Association Between Physical and Mental Health and Face Mask Use During the COVID-19 Pandemic: A Comparison of Two Countries With Different Views and Practices. Front. Psychiatry 2020, 11, 901. [CrossRef] [PubMed]

25. Lai, A.Y.-K.; Sit, S.M.-M.; Lai, T.T.-K.; Wang, M.-P.; Kong, C.H.-M.; Cheuk, J.Y.-Y.; Feng, Y.; Ip, M.S.-M.; Lam, T.-H. Facemask Wearing Among Chinese International Students From Hong Kong Studying in United Kingdom Universities During COVID-19: A Mixed Method Study. Front. Psychiatry 2021, 12, 673531. [CrossRef] [PubMed]

26. Štreimikienė, D.; Baležentis, T.; Volkov, A.; Ribašauskienè, E.; Morkūnas, M.; Žičkienè, A. Negative effects of COVID-19 pandemic on agriculture: Systematic literature review in the frameworks of vulnerability, resilience and risks involved. Econ. Res. Ekon. Istraživanja 2021, 1-17. [CrossRef]

27. Monroe, S.M.; Cummins, L.F. Stress: Psychological perspectives. Int. Ency. Soc. Behav. 2015, 583-587. [CrossRef]

28. Evans-Lacko, S.; Aguilar-Gaxiola, S.; Al-Hamzawi, A.; Alonso, J.; Benjet, C.; Bruffaerts, R.; Chiu, W.T.; Florescu, S.; de Girolamo, G.; Gureje, O.; et al. Socio-economic variations in the mental health treatment gap for people with anxiety, mood, and substance use disorders: Results from the WHO World Mental Health (WMH) surveys. Psychol. Med. 2018, 48, 1560-1571. [CrossRef]

29. WHO (World Health Organization). WHO Fact Sheet on Depression. Available online: https://www.who.int/news-room/factsheets / detail/depression (accessed on 10 October 2021).

30. Molebatsi, K.; Motlhatlhedi, K.; Wambua, G.N. The validity and reliability of the Patient Health Questionnaire-9 for screening depression in primary health care patients in Botswana. BMC Psychiatry 2020, 20, 1-10. [CrossRef] [PubMed]

31. Ragasa, C.; Lambrecht, I.; Mahrt, K.; Aung, Z.W.; Wang, M. Immediate impacts of COVID-19 on female and male farmers in central Myanmar: Phone-based household survey evidence. Agric. Econ. 2021, 52, 505-523. [CrossRef] [PubMed]

32. Vaingankar, J.A.; Abdin, E.; Chong, S.A.; Shafie, S.; Sambasivam, R.; Zhang, Y.J.; Chang, S.; Chua, B.Y.; Shahwan, S.; Jeyagurunathan, A.; et al. The association of mental disorders with perceived social support, and the role of marital status: Results from a national cross-sectional survey. Arch. Public Health 2020, 78, 1-11. [CrossRef]

33. Daré, L.O.; Bruand, P.-E.; Gérard, D.; Marin, B.; Lameyre, V.; Boumédiène, F.; Preux, P.-M. Co-morbidities of mental disorders and chronic physical diseases in developing and emerging countries: A meta-analysis. BMC Public Health 2019, 19, 1-12. [CrossRef] [PubMed]

34. Ilesanmi, F.F.; Ilesanmi, O.S.; Afolabi, A.A. The effects of the COVID-19 pandemic on food losses in the agricultural value chains in Africa: The Nigerian case study. Public Health Pract. 2021, 2, 100087. [CrossRef] [PubMed]

35. Pu, M.; Zhong, Y. Rising concerns over agricultural production as COVID-19 spreads: Lessons from China. Glob. Food Secur. 2020, 26, 100409. [CrossRef]

36. Timilsina, B.; Adhikari, N.; Kafle, S.; Paudel, S.; Poudel, S.; Gautam, D. Addressing Impact of COVID-19 Post Pandemic on Farming and Agricultural Deeds. Asian J. Adv. Res. Rep. 2020, 11, 28-35. [CrossRef]

37. Sampson, S.; Mazur, J.; Israel, G.; Galindo, S.; Ward, C. Competing Roles and Expectations: Preliminary Data from an Agricultural Extension Survey on COVID-19 Impacts. J. Agromed. 2020, 25, 396-401. [CrossRef] [PubMed]

38. Paul, A.; Nath, T.K.; Mahanta, J.; Sultana, N.N.; Kayes, A.S.M.I.; Noon, S.J.; Jabed, A.; Podder, S.; Paul, S. Psychological and Livelihood Impacts of COVID-19 on Bangladeshi Lower Income People. Asia Pac. J. Public Health 2021, 33, 100-108. [CrossRef]

39. Monetary Policy Report March 2020. Government Relief Measures to Alleviate the Impact of COVID-19. Available online: https://www.bot.or.th/English/MonetaryPolicy/MonetPolicyComittee/MPR/BOX_MRP/BOX1_MPRMarch2020_ COVID19.pdf (accessed on 20 September 2021).

40. Thanachaisethavut, B. Informal Workers and Legal Protection in Thailand. Available online: https://www.wiego.org/sites/ default/files/reports/files/T01.pdf (accessed on 30 November 2021).

41. Komin, W.; Thepparp, R.; Subsing, B.; Engstrom, D. COVID-19 and its impact on informal sector workers: A case study of Thailand. Asia Pac. J. Soc. Work Dev. 2020, 31, 80-88. [CrossRef]

42. Sapbamrer, R. Pesticide Use, Poisoning, and Knowledge and Unsafe Occupational Practices in Thailand. New Solut. J. Environ. Occup. Health Policy 2018, 28, 283-302. [CrossRef] 
43. Forum on Public-Private Partnerships for Global Health and Safety; Board on Global Health; Institute of Medicine; National Academies of Sciences, Engineering, and Medicine. Approaches to Universal Health Coverage and Occupational Health and Safety for the Informal Workforce in Developing Countries: Workshop Summary. Washington (DC): National Academies Press (US), 6 June 2016. 4, Responding to Work-Related Health Needs of Informal Sector Workers. Available online: https:/ /www.ncbi.nlm.nih.gov / books/NBK373407 / (accessed on 30 November 2021).

44. McDaid, D. Viewpoint: Investing in strategies to support mental health recovery from the COVID-19 pandemic. Eur. Psychiatry 2021, 64, e32. [CrossRef] [PubMed]

45. Stewart, D.E.; Appelbaum, P.S. COVID -19 and psychiatrists' responsibilities: A WPA position paper. World Psychiatry 2020, 19, 406-407. [CrossRef] [PubMed] 